\title{
FACTORS THAT DETERMINE TOURIST'S PURCHASE INTENTION TOWARD KELANTANESE LOCAL CUISINE
}

\author{
Nurul Fardila Abd Razak', Abdullah Muhamed Yusoff ${ }^{2}$ Nur Azimah Othman ${ }^{3}$, Derweanna Bah Simpong ${ }^{4}$ \\ \& Noriza Ishak ${ }^{5}$ \\ 1,2,3,4Faculty of Hospitality, Tourism and Wellness, Universiti Malaysia Kelantan, Kota Bharu, Malaysia \\ ${ }^{5}$ Faculty of Hotel and Tourism Management, UiTM Selangor Puncak Alam Campus, Selangor, Malaysia \\ (fardilarazak@gmail.com)
}

\begin{abstract}
Local foods are one of the cravings of travelers wanting to experience the joys of domestic tourism. Some of the other reasons tourists visit a place is to experience the lifestyle, and culture. Besides these motivational factors, tourist visit places based on word -of- mouth and their own past experiences. The state of Kelantan, Malaysia is identified as a vibrant tourist destination as it has beautiful natural environs and has a rich and diverse cultural heritage that is easy to promote to tourists. Kelantan is also well known for its local cuisines that can attract the foodies. The uniqueness of the local cuisine also influences tourists to make other purchases. Using the quantitative research approach, this study aims to identify the relationship between food quality, price, and service quality towards the tourists intention to purchase local cuisine in Kelantan. These three independent variables will have a different role in explaining the factors that influence a tourist's intent to purchase Kelantanese foodstuff.
\end{abstract}

KEYWORDS: Food Quality, Price, Service Quality, Purchase Intention \& Kelantan Cuisine

\section{PURPOSE AND BACKGROUND}

Food has often been considered a key attraction for visitors to a destination. In Southeast Asia, Malaysia is known as the one of the countries which offers glorious food products that promote domestic and international tourism (Jalis, Salehuddin, Zahari \& Othman, 2009). The Malaysian government has identified the tourism sector as a high priority growth sector and therefore the government is aggressively promoting Malaysia on the world stage (Tourism Malaysia, 2021).

A recent tourism activity making waves is nurturing the tourist experiences that revolve around the local foods and the pursuit of memorable tourist experiences (Hashemi, Mohammed, Kiumarsi, Hung Kee, \& Anarestani, 2021). According to Karim and Chi, (2010) food influences the tourist's loyalty and causes them to visit the destination more than once.

However, there are insufficient studies that investigate the outcome of the gastronomic experience on the tourists' intentions towards the destination and the local food on offer. According to Nam (2017), there are several countries that have made extensive use of local foods as a primary tourism activity, these include, Spain, France, Hong Kong, Thailand, and Singapore, and all of them have become popular tourist destinations.

As such Kelantan is well-known for its cultural, heritage and natural environment. However, according to Abdullah, Teo and Foo (2016), food production in Kelantan has consistently added to the states revenues.

The states local foods are frequently cited as an important factor that lures tourists to the state. Despite the growing number of tourists arrivals; there is very minimal research and data on the consumption of 
local Kelantanese cuisine by tourists. Therefore, this paper aims to examine the gap between the tourist's intention to purchase local Kelantanese delicacies and the foodstuffs that are being developed to attract tourists to the state as symbolic cultural heritage items in Kelantan.

\section{METHODOLOGY}

This study used a quantitative approach, and the questionnaire is developed through a review of the literature. The instruments for this study were adopted and adapted from the work of several scholars, such as the food quality (Hanaysha, 2016); Price and service quality from Muskat, Hörtnag, Prayag and Wagner (2019) and purchase intention from Nam, Shim and Jeong (2017).

The questionnaire survey consists of (3) sections and self-administrated. This study is intended for the domestic and international tourists who are travelled visiting Kelantan and intend to try the local cuisines. Therefore, this study uses the convenience sampling technique as the sampling method in which this approach provides the researcher with a generalised sample (Sharma, 2017).

This study has 384 respondents representing a population of more than 6.5 million people, as suggested by Krejie and Morgan (1970). The data was analysed by using the Statistical Package for Social Sciences (SPSS), version 26. In this study, the items were measured by using a 5-point Likert scale and carried out a pre-test activity at two levels to ensure the question items' validity.

The viewpoints of experts from the Department of Tourism, Faculty of Hospitality, Tourism and Wellness' were also considered and used to modify the questions in some cases. A pilot study was then conducted before the mass data collection process. A total of 30 sets of the questionnaires were analysed for reliability purposes. All items achieved an acceptable Cronbach's alpha value, as shown in Table 1.

Table 1: Results of reliability Cronbach's Alpha for this study

\begin{tabular}{ccc}
\hline Variables & Number of Items & Cronbach's Alpha \\
\hline Food Quality & 7 & 0.940 \\
Price & 7 & 0.850 \\
Service Quality & 7 & 0.945 \\
Purchase Intention & 7 & 0.911 \\
\hline
\end{tabular}

\section{FINDINGS}

Table 2: Pearson Correlation Coefficient

\begin{tabular}{lc}
\hline \multicolumn{1}{c}{ Variables } & Pearson Correlation \\
\hline Food Quality & $.812^{* *}$ \\
Price & $.802^{* *}$ \\
Service Quality & $.819^{* *}$ \\
\hline **. Corelation is significant at the 0.01 level (2-tailed) \\
\hline
\end{tabular}

Based on Table 2, there is a significant, strong, and positive correlation between food quality and factors that influence visitors' intention to purchase Kelantanese cuisine. The relationship between the food quality is 0.812 , which R-value was positive, indicating linear correlation was high at p-value 0.000.

This indication is supported by Xiao, Yang and Iqbal (2018), stated that food quality is the most influential factor influencing the purchasing intent for all industries. There is a significant, strong, 
and positive correlation between price and factors that influence visitors' purchase intention towards Kelantanese cuisine. The relationship between the price is 0.802 , which R-value was positive, indicating linear correlation was high at p-value 0.000 .

In the restaurants, customers' expectations might not be the same, regardless of the same service suppliers' availability, making the perception of prices on customer behaviour the most influential (Shahzadi, Malik Shahab, Ahmad, \& Shabbir, 2018). There is a significant, strong, and positive correlation between service quality and factors influencing visitors' intention to purchase Kelantanese cuisine.

The relationship between the food quality is 0.819 , which R-value was positive, indicating linear correlation was high at p-value 0.000. Based on the previous study done by Shahzadi et al. (2016), it was found that customers often have high expectations from services, especially in service settings. Hence, they need to receive higher quality service to be delighted with the service and to ensure that they revisit them.

\section{CONCLUSION}

This study examined the connection between the impacts of identification, tangible aspects, and responsiveness that influence visitor's purchase intention towards Kelantanese cuisine. The findings of this study can be used to design marketing strategies and local government tourist policy linked to gastronomic tourism and contribute to academic literature gaps. Thus, from the marketers' perspective, they should understand the characteristics of food tourists who like food tourism to establish any promotion activities.

This research aims to help small and medium entrepreneurs (SME) food enterprises identify the impacts of visitors' purchase intention toward Kelantanese cuisine. Moreover, the research framework was developed and supported according to the literature that had been viewed. It can be concluded that Kelantan can promote gastronomy tourism as attractiveness to reflect its food cuisine. This study has some limitations that might be dealt with in future research. Hence, it is crucial to investigate how Kelantan's cuisine is reflected in various businesses and determine the perceived food image.

\section{REFERENCES}

Ab Karim, S., \& Chi, C. G. Q. (2010). Culinary tourism as a destination attraction: An empirical examination of destinations' food image. Journal of Hospitality Marketing \& Management, 19(6), 531-555.

Department of Statistics Malaysia. (2019). Socio-economic Report, State of Kelantan 2019. https://www. dosm.gov.my/v1/uploads/files/1_Articles_By_Themes/National\%20Accounts/GDPbyState/2020/ Laporan_Sosioekonomi_Kelantan_2019.pdf

Hanaysha, J. (2016). Testing the effects of food quality, price fairness, and physical environment on customer satisfaction in the fast-food restaurant industry. Journal of Asian Business Strategy, 6(2), 31-40.

Muskat, B., Hörtnagl, T., Prayag, G., \& Wagner, S. (2019). Perceived quality, authenticity, and price in tourists' dining experiences: Testing competing models of satisfaction and behavioral intentions. Journal of Vacation Marketing, 25(4), 480-498.

Shiva Hashemi, Husam Jasim Mohammed, Shaian Kiumarsi, Daisy Mui Hung Kee \& Behnaz Babaei Anarestani. (2021). Destinations food image and food neophobia on behavioral intentions: Culinary tourist behavior in Malaysia. Journal of International Food \& Agribusiness Marketing. 